\title{
Onion Thrips (Thysanoptera: Thripidae): A Global Pest of Increasing Concern in Onion
}

\author{
JOHN DIAZ-MONTANO,${ }^{1,2}$ MARC FUCHS,${ }^{3}$ BRIAN A. NAULT, ${ }^{1}$ JÓZSEF FAIL, ${ }^{4}$ \\ AND ANTHONY M. SHELTON ${ }^{1}$
}

J. Econ. Entomol. 104(1): 1-13 (2011); DOI: 10.1603/EC10269

\begin{abstract}
During the past two decades, onion thrips, Thrips tabaci Lindeman (Thysanoptera: Thripidae), has become a global pest of increasing concern in commercial onion (Allium cepa L.), because of its development of resistance to insecticides, ability to transmit plant pathogens, and frequency of producing more generations at high temperatures. T. tabaci feeds directly on leaves, causing blotches and premature senescence as well as distorted and undersized bulbs. T. tabaci can cause yield loss $>50 \%$ but can be even more problematic when it transmits Iris yellow spot virus (family Bunyaviridae, genus Tospovirus, IYSV). IYSV was identified in 1981 in Brazil and has spread to many important onion-producing regions of the world, including several U.S. states. IYSV symptoms include straw-colored, dry, tan, spindle- or diamond-shaped lesions on the leaves and scapes of onion plants and can cause yield loss up to $100 \%$. Here, we review the biology and ecology of T. tabaci and discuss current management strategies based on chemical, biological, and cultural control as well as host resistance. Future directions for research in integrated pest management are examined and discussed.
\end{abstract}

RESUMEN En las ultimas dos décadas, el trips de la cebolla, Thrips tabaci Lindeman (Thysanoptera: Thripidae), se ha convertido en una plaga mundial de alto interés en cebolla, Allium cepa L., debido a su desarrollo de resistencia a insecticidas, capacidad para transmitir patógenos en plantas, y producción de mayor numero de generaciones a altas temperaturas. T. tabaci se alimenta directamente sobre las hojas causando manchas, senescencia prematura, así como bulbos pequeños y desformados. T. tabaci puede causar perdidas en rendimiento mayores al $50 \%$, pero esta plaga puede ser aun más problemática cuando transmite Iris yellow spot virus (family Bunyaviridae, genus Tospovirus, IYSV). IYSV fue identificado en Brasil en 1981 y desde entonces se ha propagado a importantes regiones productoras de cebolla a nivel mundial, incluyendo diferentes estados en los Estados Unidos. Los síntomas del IYSV incluye lesiones secas en forma angular o de diamante, de color café claro en las hojas y tallos de la cebolla y puede producir hasta $100 \%$ de perdidas en rendimiento. En este articulo nosotros revisamos la biología y ecología de T. tabaci y presentamos los actuales métodos de manejo basados en control químico, biológico y cultural así como el método de resistencia de plantas a insectos. Las direcciones futuras para investigación en manejo integrado de esta plaga son analizadas.

KEY WORDS Thrips tabaci, Allium cepa, Iris yellow spot virus, management

Onion thrips, Thrips tabaci Lindeman (Thysanoptera: Thripidae), has been the subject of considerable research and extension publications since it was first described in 1888 (Lindeman 1889). Some aspects of its biology, ecology, and management have been summarized in T. Lewis' highly regarded 1997 book, Thrips as Crop Pests, but a considerable amount of detail

\footnotetext{
${ }^{1}$ Corresponding author: Department of Entomology, Cornell University-NYSAES, $630 \mathrm{~W}$. North St., Geneva, NY 14456 (e-mail: jd325@cornell.edu).

${ }_{2}^{2}$ Current address: Department of Entomology, University of California, Riverside, CA 92521.

${ }^{3}$ Department of Plant Pathology, Cornell University-NYSAES, 630 W. North St., Geneva, NY 14456.

${ }^{4}$ Department of Entomology, Corvinus University of Budapest, 29-43 Villányiút, Budapest, H-1118.
}

important for its management on onion (Allium cepa L.) was not included or has developed since its publication. For example, in many parts of the world Iris yellow spot virus (family Bunyaviridae, genus Tospovirus, IYSV), which infects onion and is only transmitted by T. tabaci, has caused serious losses in several countries but is not mentioned in the book. Furthermore, management of T. tabaci specifically on onion was not emphasized in the book, but onion is a major vegetable crop that was harvested on 198,913 ha (green onions) and 3,731,659 ha (dry onions) worldwide in 2008 (FAO 2009), and T. tabaci is an increasingly difficult pest to control on this crop. Our purpose in this review is to highlight important aspects of the history, biology, ecology, and management of T. tabaci as it pertains to onion and to stimulate 
discussion for future work on this important global pest of onion.

\section{Taxonomy, Origin, Host Range, and Geographic Distribution of T. tabaci}

T. tabaci was first described by the Russian entomologist Karl Eduard Lindeman, based on specimens collected in Bessarabia, Russia, that caused severe damage to tobacco (genus Nicotiana) plants (Lindeman 1889). T. tabaci belongs to the order Thysanoptera, suborder Terebrantia, family Thripidae, and subfamily Thripinae (Mound and Walker 1982). T. tabaci is believed to be a native of the eastern Mediterranean (Mound and Walker 1982, Mound 1997), which is the center of origin for its most important host plant, i.e., onion (Mound 1997). T. tabaci has a wide host range compared with other thrips species. Some reports list T. tabaci on 141 plant species in 41 families (Ghabn 1948), whereas others list it on $>355$ species of flowering plants (Morison 1957), and still others list it on 140 plant species within 40 families (Ananthakrishnan 1973). Despite its large host range, onion is a favorite host and is one of the few crops attacked by the same species in different parts of the world (Lewis 1973, 1997b). T. tabaci is a cosmopolitan pest of onion grown between sea level and 2,000 m (Lewis 1973, 1997b). It is present in Europe, North America, South America, Africa, Asia, and Australia (Mound 1997). In the second half of the 19th century, several studies reported a thrips species called "onion thrips" causing damage to onion crops in the United States and in the Bermuda Islands, but the species was either misidentified (Packard 1872, Gillette 1893, Osborn and Mally 1895) or not identified at all (Shipley 1887, Thaxter 1890). Theodore Pergande, an American entomologist, after carefully examining and comparing the $T$. tabaci specimens sent to him by Karl E. Lindeman with the specimens of the so called "onion thrips," collected from onion and several other host plants in the United States, confirmed that they were in fact the same species (Pergande 1895). Since then, the thrips species reported causing damage on onion (Slingerland 1896, Webster 1901, Chittenden 1913) has been called onion thrips in the English literature. Despite the fact that the first description of T. tabaci was published in Europe in 1889, the species had been collected between 1882 and 1888 on onion; cabbage, Brassica oleracea L.; cucumber, Cucumis sativus L.; and parsley, Petroselinum crispum L.; and then identified correctly by Pergande in North America for the first time in the early 1890s (Pergande 1895). T. tabaci spread subsequently throughout the United States and southern Canada by the early 1900s (Capinera 2001). T. tabaci is considered a pest of significant economic importance on different plant species during dry weather in temperate and subtropical regions (Morison 1957).

\section{Morphology, Development, and Reproduction of T. tabaci}

T. tabaci adults vary from pale yellow to dark brown (Morison 1957, Mound 1967, Nakahara 1991, Triplehorn and Johnson 2005), depending on temperature during their development (Sakimura 1937, Murai and Toda 2001). Adult T. tabaci that develop faster during the summer or at high temperatures are usually smaller and paler than those that develop slowly during winter or lower temperatures (Mound 1997). T. tabaci females vary in size and color from small pale to large dark, probably in response to temperature during development (Mound 1973); males are smaller and paler than females (Morison 1957). Murai and Toda (2001) demonstrated that T. tabaci adult body color and size are determined by temperature during the pupal and larval stages, respectively. Generally, adult females are 1.0-1.3 mm in length (Morison 1957), and males are $\approx 0.7 \mathrm{~mm}$ in length (Pergande 1895).

As with all Terebrantia, the life cycle of T. tabaci consists of an egg, first and second larval instars (L1 and L2), prepupa, pupa, and adult (Ghabn 1948, Nakahara 1991). Another stage of T. tabaci was described by Gawaad and El-Shazli (1970) as the "prenymph," an apodous larva with a developed head and two red eyes that has not completely escaped from the egg pocket. Eggs are kidney shaped and are inserted either in the upper or lower surface of a leaf very close to the surface and always inserted diagonally at $\approx 60^{\circ}$ (Gawaad and El-Shazli 1970). Eggs are $\approx 0.26 \mathrm{~mm}$ in length (Ghabn 1948).

It is difficult to identify $T$. tabaci larvae from other thrips species. In Egypt, Ghabn (1948) compared T. tabaci to other thrips species and observed that larvae of $T$. tabaci have the shortest macrosetae (lateral bristles of the prothorax), $\approx 20 \mu \mathrm{m}$. Also, the larvae do not have the dark gray chitinous markings on the dorsum of the thorax, which is present in many other thrips species. Finally, the tiny elements of the sculpture of the abdomen consist of pointed small protuberances, whereas in other thrips species these elements are larger and rounded. In general, larvae of the family Thripidae have seven-segmented antennae, three thoracic segments and a pair of spiracles on the mesothorax, and a 10-segmented abdomen with a pair of spiracles on abdominal segments II and VIII. The first instar differs from the second instar by having six pairs of setae on the pronotum and four pairs of setae on abdominal segments III-VII. The second instar has seven pairs of setae on the pronotum and six pairs of setae on abdominal segments III-VII (Nakahara 1991). The short third antennal joint and the pointed terminal joint distinguish the first instar of T. tabaci, whereas the antenna of the second instar is more slender and the terminal joint is rounded at the tip. Recently, a comprehensive identification key to the second instar larvae of 130 species of Thripidae, including T. tabaci, has been published by Vierbergen et al. (2010).

The prepupa and pupa of T. tabaci differ from the larvae by the presence of wing sheaths (Ghabn 1948). The prepupa and pupa of $T$. tabaci can be differentiated by the development and orientation of the antennae and the length of the antennae and wing sheaths (Ghabn 1948).

Adult T. tabaci have a gray or yellowish gray ocellar pigment (Morison 1957, Stannard 1968), front wing 
Table 1. Development stages (days) of T. tabaci on onion

\begin{tabular}{|c|c|c|c|c|c|c|c|c|c|c|c|}
\hline $\begin{array}{c}\text { Temp } \\
\left({ }^{\circ} \mathrm{C}\right)\end{array}$ & Egg & Ll & L2 & Prepupa & Pupa & $\begin{array}{c}\text { Total } \\
\text { (d from egg } \\
\text { to adult) }\end{array}$ & Preoviposition & Oviposition & $\begin{array}{l}\text { Eggs/ } \\
\text { female }\end{array}$ & $\begin{array}{c}\text { Adult } \\
\text { longevity }\end{array}$ & Reference \\
\hline & 3.6 & \multicolumn{2}{|c|}{6.4} & 1.2 & 3.2 & 14.4 & 2.8 & 49.6 & 80.1 & 58.2 & Sakimura (1937) \\
\hline & 5.6 & \multicolumn{2}{|c|}{8.6} & 2.0 & 4.2 & 20.4 & 3.9 & 44.2 & 53.9 & 51.7 & \\
\hline 15.8 & 8.5 & \multicolumn{2}{|c|}{6.5} & 2.0 & 4.0 & 21.0 & & & 49.8 & 18.8 & Lall and Singh (1968) \\
\hline 18.0 & 7.9 & \multicolumn{2}{|c|}{6.2} & 2.0 & 3.5 & 19.6 & & & 51.7 & 19.6 & \\
\hline 23.4 & 6.0 & \multicolumn{2}{|c|}{5.5} & 1.7 & 2.8 & 16.0 & & & 55.0 & 20.1 & \\
\hline 30.8 & 4.8 & \multicolumn{2}{|c|}{5.3} & 1.4 & 2.4 & 13.9 & & & 28.2 & 20.2 & \\
\hline 25.0 & 3.4 & 2.4 & 2.8 & 2.2 & 3.1 & 13.9 & 1.4 & 15.6 & 23.6 & 17.8 & Gawaad and El-Shazli (1971) \\
\hline 17.5 & 15.1 & \multicolumn{4}{|c|}{15.3} & 30.4 & 5.7 & & & & Edelson and Magaro (1988) \\
\hline 27.5 & 4.3 & \multicolumn{4}{|c|}{6.8} & 11.1 & 1.0 & & & & \\
\hline 32.0 & 4.33 & 2.09 & 2.04 & 1.17 & 2.4 & 12.0 & 2.7 & 19.5 & 37.0 & 21.5 & Salas et al. (1993) \\
\hline 23.4 & 4.6 & 2.06 & 4.03 & 1.2 & 2.3 & 14.2 & $4-6$ & 15.2 & 40.65 & 21.5 & Guzman et al. (1996) \\
\hline 23.4 & 3.2 & 2.7 & 2.9 & 1.9 & 3.5 & 14.2 & 2.0 & 8.0 & 39.0 & 11.5 & Arrieche et al. (2006) \\
\hline
\end{tabular}

with four setae (occasionally two to six) on the distal half of first-vein (Moritz et al. 2001), seven-segmented antennae (Mound and Walker 1982, Bournier 1983) with the first and the base of segments three and four lighter than the others (Stannard 1968), and do not have the accessory setae on the abdominal sternites (Bournier 1983). The grayish ocellar crescent distinguishes T. tabaci from most species in Thripidae, which have orange to red ocellar crescents. Other diagnostic characters are the short posteroangular setae present on the pronotum, and the posteromarginal comb on abdominal segment VIII with long, close-set teeth (Nakahara 1991, 1994), which is complete dorsally; pronotal bristles $33-45 \mu \mathrm{m}$ long without accessory bristles on abdominal sternites (Morison 1957) and pleurotergites without discal setae but with sculpture of rows of fine microtrichia (Moritz et al. 2001).

Only a few thrips species, such as T. tabaci, reproduce by parthenogenesis (Moritz 1997), which is the production of offspring without fertilization by a male (Ananthakrishnan 1990). In the eastern Mediterranean and Iran, the sex ratio of T. tabaci was 1:1 (Lewis 1973, Mound 1973), suggesting that the population was sexually reproducing; but in most temperate regions of the world, only parthenogenetic forms of $T$. tabaci have been reported (Lewis 1973, Kendall and Capinera 1990).

Thelytoky is the most common reproductive mode in T. tabaci (Lewis 1973, Kendall and Capinera 1990). Thelytoky is a type of parthenogenesis in which unfertilized eggs develop into females (Lewis 1973). T. tabaci also can reproduce by arrhenotoky (Kendall and Capinera 1990), in which unfertilized eggs develop into males and fertilized eggs into females. Deuterotoky is an uncommon parthenogenetic mode of reproduction in thrips and was reported for the first time occurring in T. tabaci by Nault et al. (2006). Deuterotoky occurs when unfertilized eggs develop into either males or females.

In New York, Gangloff (1999) reported for the first time the presence of male T. tabaci in different fields in a commercial onion-growing region (Yates County). In research conducted from 2001 to 2002 in Canada, MacIntyre-Allen et al. (2005a) studied the sex ratio of T. tabaci in onion fields by using water pan and sticky traps and found that $100 \%$ of the T. tabaci captured were females. In addition, T. tabaci populations collected from the field in 2000 and reared in laboratory conditions until 2004 did not produce males. In New York, Nault et al. (2006) sampled T. tabaci in 20 onion fields from six different counties and found half of the population was thelytokous with the other half being a mix of thelytokous, arrhenotokous, and deuterotokous. The various reproduction systems of $T$. tabaci probably contribute to it becoming more problematic because, for example, thelytokous individuals are not dependent on finding mates and, if they are resistant to an insecticide, then their offspring will be as well.

Usually, T. tabaci overwinter as adults (Shirck 1951, Lewis 1973, North and Shelton 1986b, Sites and Chambers 1990). Sites and Chambers (1990) found that temperature induces diapause in T. tabaci populations and eggs can be laid as soon as temperature increases during the spring. T. tabaci lay eggs where they feed and move continually to younger tissue (Theunissen and Legutowska 1991). T. tabaci lay more eggs and develop faster on onion leaves than on onion bulbs (Gawaad and El-Shazli 1970); however, they lay their eggs indiscriminately on leaves, cotyledons, petals, sepals, and glumes (Lewis 1973). Compared with other thrips species, T. tabaci lay $\approx 3$ times more eggs during the first $10 \mathrm{~d}$ of oviposition than in the last $10 \mathrm{~d}$ (Sakimura 1937), which allows a rapid establishment of large populations.

In Table 1, we present a summary of different studies of T. tabaci developmental time on onion under different temperatures. The short developmental time and high fecundity of T. tabaci often results in population outbreaks.

\section{Seasonal Patterns of T. tabaci on Hosts in the Onion Cropping System}

T. tabaci infests crops that are ephemeral in the landscape. For example, onions are generally in the ground for 3 mo before they are harvested so insects such as thrips must evolve strategies that can deal with continuously changing habitats. Understanding the factors that influence their movement patterns, espe- 
cially in the varied landscapes onion is often grown in, may provide insight into enhanced management in crops such as onion.

Horsfall (1921) investigated the sources of infestation of T. tabaci and found that it became a problem for onion only after nearby fields of alfalfa, Medicago sativa $\mathrm{L}$., were established for two consecutive seasons. In this study, dispersal flights were observed soon after alfalfa was cut. Similarly, North and Shelton (1986a) observed many thrips in cabbage fields only when maturation and/or mowing of other field and forage crops occurred. Overwintering populations in field and forage crops are important sources of $T$. tabaci that infest vegetable crops (North and Shelton 1986a,b; Weiss and Beshear 1987; Chambers and Sites 1989). However, such sites are not the only source for T. tabaci. Larentzaki et al. (2007) found that T. tabaci overwinters in the soil within onion fields and surrounding vegetation and that volunteer onion plants could be important hosts for thrips before the newly planted onion crop emerges in the spring. T. tabaci also colonized volunteer onion plants left in the field in the fall, as well as weed species such as pigweed, Amaranthus hybridis L.; and lambsquarters, Chenopodium album L. (Larentzaki et al. 2007). T. tabaci also was found on several other weed species listed by Ghabn (1948), Morison (1957), Ananthakrishnan (1973), and Smith (2010).

Thus, it is clear that onion areas, especially those that are grown continuously to onion such as the typical muck areas in the northeastern United States, may be more of a "closed system" than was previously assumed. This has important ramifications for control practices because insecticide use in an individual field may cause localized resistance, which may become a perennial problem if immigration of susceptible individuals is limited and resistance is stable. Localized patterns of resistance have been observed in the onion growing regions of New York (Shelton et al. 2003, 2006) lending evidence to the idea of a more closed system. Harding (1961) also studied the effect of migration on T. tabaci populations and observed minimal movements of thrips to onion crops and attributed damage to within-field movements and reproduction, rather than to migration.

Abundance and distribution of T. tabaci in onion fields are affected by agricultural practices within and near onion fields. Early in the season, T. tabaci populations are significantly higher in onion fields initiated from transplants compared with those initiated from seed, presumably because transplanted onions are much larger and likely more attractive to thrips at the time of colonization (Hsu et al. 2010). Once an onion field is colonized, the distribution and abundance of thrips may change over time. In Texas, Edelson et al. (1986) reported that within-field populations of $T$. tabaci increased progressively through the season and the largest numbers were observed just before harvest. In New York, Shelton et al. (1987) found that the pattern of onion thrips distribution between plants was random although there were some edge effects, suggesting some movement into the field from sur- rounding areas. Similar edge effects in onion were found by Horsfall (1921) in Iowa and attributed to harvesting of nearby alfalfa fields. On a within-plant level, Sites et al. (1992) observed that during the onion vegetative stage, T. tabaci populations were concentrated on the center leaves but progressively populations became equally distributed all over the leaves. Mo et al. (2008) observed that when onion plants were young and T. tabaci densities were low, higher numbers of larvae than adults gathered at the base of plants. When onion plants matured and thrips densities increased, the larvae dispersed to other parts of the leaves. At all times, more adults were found in the upper than in the basal sections of the plant. Eggs were laid all over the plant, but leaves of intermediate ages had more eggs than younger and older leaves.

\section{Environmental Effects on T. tabaci Outbreaks}

Hot and dry weather promotes the increase of $T$. tabaci populations (Bailey 1934, Rueda et al. 2007) and the severity of thrips injury (Lewis 1973). However, it is difficult to determine if the effect is nutritional or due to the reduction of mortality from rain (Kirk 1997). It also has been suggested that water stress may increase the nutritional quality of the plant, increasing attractiveness of the plant to thrips (Lewis 1973). After heavy rains, thrips species, such as T. tabaci, can be washed off plants (Harris et al. 1935, North and Shelton 1986a).

The number of T. tabaci on onion can be enormous. Lewis (1973) estimated T. tabaci densities of 740$1,600 \times 10^{6} \mathrm{ha}^{-1}$ for larvae on onion in the United States. Srinivasan et al. (1981) sampled an onion field with an average of 10.9 thrips per plant, and the distribution was clumped. Edelson et al. (1986) found that when T. tabaci density was more than one thrips per plant the distribution was clumped, but when it was less than one thrips per plant, the distribution was more uniform or not significantly different from a random distribution. Shelton et al. (1987) found some "hot spots" where T. tabaci was concentrated along the borders in some of the six commercial onion fields sampled during the middle of the growing season but that the distribution throughout the field was essentially random.

\section{Damage Caused by T. tabaci on Onion}

T. tabaci is considered an indirect pest of dry bulb onion because it feeds on leaves rather than the marketable portion of the crop, the bulb. Thrips feeding on onion causes silvery leaf spots that turn into white blotches along the leaves due to removal of cellular content followed by the development of silvery patches and curling of leaves (Bailey 1938). This injury reduces the photosynthetic ability of the plant (Molenaar 1984, Parrella and Lewis 1997) by destroying chlorophyll-rich leaf mesophyll (Molenaar 1984), and this may interfere with transportation of nutrients to the bulb (Parrella and Lewis 1997). Damage to onion caused by T. tabaci induces greater ethylene 
production (Kendall and Bjostad 1990) when the saliva from thrips salivary glands comes into contact with damaged tissues on the plant (Kendall and Capinera 1990), and this induces ripening (bulb swelling) and senescence of leaves (Levy and Kedar 1970, Jackson and Osborne 1970). Thus, thrips infestations at the end of the growing season may help prepare the onion crop for harvest. However, permitting damage to occur late in the season could allow pathogens to infect the plant causing quality reductions in storage (Mayer et al. 1987).

T. tabaci still causes significant yield loss despite decades of research on control strategies worldwide (Lewis 1997b). T. tabaci feeding can reduce onion bulb weight (Kendall and Capinera 1987, Fournier et al. 1995, Rueda et al. 2007, Diaz-Montano et al. 2010) and cause up to $60 \%$ yield loss (Waiganjo et al. 2008). Young onion plants are more susceptible and prone to be killed by high T. tabaci infestations (Lewis 1973) and are relatively insensitive to thrips feeding late in the season; however, the damage increases with water stress (Parrella and Lewis 1997). Besides damage to the onion crop, T. tabaci adults and larvae also can feed on flower pedicels and buds and reduce seed yield in onions grown for seed production (Elmore 1949).

In addition to injury by feeding, T. tabaci transmits IYSV and is the only confirmed vector of this pathogen (Pozzer et al. 1999, Kritzman et al. 2001). IYSV was first identified on onion in southern Brazil in 1981 (Pozzer et al. 1994) and was confirmed in the United States in 1989 in Idaho and Oregon (Hall et al. 1993). IYSV has spread to other important onion-producing U.S. states and worldwide (Gent et al. 2006). IYSV symptoms on leaves appear as lesions (i.e., straw-colored to white, dry, and sometimes elongate) along the edges (Gent et al. 2006). Studies conducted in Colorado (Gent et al. 2004) indicate that IYSV infection can reduce bulb size (Gent et al. 2004) and cause 100\% crop loss (Pozzer et al. 1999). Many onion cultivars have been tested in field conditions, and all of them became infected with the virus (du Toit and Pelter 2005, Diaz-Montano et al. 2010). In New York, where the virus was found recently (Hoepting et al. 2007), symptoms of IYSV were mild to absent and appeared late in the season (Diaz-Montano et al. 2010, Hsu et al. 2010), which suggests that reductions in plant size and bulb weight were probably due to $T$. tabaci feeding rather than IYSV (Diaz-Montano et al. 2010). However, if IYSV infects onion plants early in the growing season, onion yield losses may increase (Diaz-Montano et al. 2010).

Feeding by T. tabaci can increase the incidence of the fungal pathogen Botrytis allii Munn in stored onions (Mayer et al. 1987). Onion plants with both $T$. tabaci and Alternaria porri (Ellis), the causal agent of purple blotch of onion, had larger lesions and suffered more damage. The fungus enters onion leaves through stomata and the epidermal cell layer but penetrates easier when the leaf surface has been damaged by thrips. In addition, the infection moved from old leaves to young leaves where T. tabaci feeds (Thind and Jhooty 1982, McKenzie et al. 1993). Studies strongly suggest that $T$. tabaci predisposes onion plants to A. pori; therefore, measures against $T$. tabaci should be considered while planning control of purple blotch of onion (Thind and Jhooty 1982).

\section{Treatment Guidelines for T. tabaci on Onions}

Treatment guidelines for T. tabaci on onion are impacted by a number of environmental and biological factors and vary regionally. Edelson et al. (1986) found that low populations of T. tabaci, approximately nine thrips per plant for the whole season, did not impact onion yield significantly, but a population of 24 thrips per plant had a significant negative effect on yield. Other studies showed yield losses varying from $43 \%$ (Fournier et al. 1995) to $60 \%$ (Waiganjo et al. 2008). The greatest reduction in yield has been observed at the bulbing stage when populations are not controlled; only 10 thrips per plant can cause a $2-3$ and $7 \%$ bulb reduction in field and greenhouse conditions, respectively (Kendall and Capinera 1987).

It is difficult to determine accurate economic injury thresholds to onion because injury is caused indirectly by $T$. tabaci feeding on leaves rather than on the bulbs. However, some studies have been conducted. In Canada, Fournier et al. (1995) determined that seasonal (1988-1990) averages of 149 and 172 T. tabaci per plant resulted in yield losses of 35 and $43 \%$ in untreated plots, respectively, whereas an average of 35 thrips per plant did not cause significant losses. The economic thresholds calculated were 2.2 and 0.9 thrips per leaf for 1988 and 1989, respectively. In other studies, the following economic thresholds were recommended for T. tabaci on onion: three thrips per leaf in New York (Shelton et al. 1987); one thrips per leaf in Texas (Edelson et al. 1989); 0.9 thrips per leaf under early and severe drought conditions and 2.2 thrips per leaf during a season with a slight water deficit in Canada (Fournier et al. 1995); and 0.5 and 1.6 thrips per leaf during the dry season in Honduras (Rueda et al. 2007). There is not a unique economic threshold for thrips on onion (Fournier et al. 1995) or for any given pest without considering weather conditions (Pedigo et al. 1986, Fournier et al. 1995) or the efficacy of the insecticide used (Nault and Shelton 2010). The use of economic threshold for T. tabaci on onion should be implemented for farmers to change the persistent calendar application of chemical insecticides, which has led to development of T. tabaci resistance to insecticides; however, as mentioned, the determination of economic injury thresholds depends on several factors such indirect damage on leaves, weather conditions, and insecticide efficacy. Furthermore, in some locations more than one economic threshold may have to be determined, one threshold for the rainy season and another for dry season (Rueda et al. 2007). Thus, farmers may need to establish their own economical threshold based on their unique conditions and this complexity may cause them to revert to calendarbased applications. 


\section{Management of T. tabaci in Onions}

The most common method to control T. tabaci populations is the use of foliar insecticides, but T. tabaci is difficult to control because insects are found mainly in the narrow spaces between the inner leaves (Shelton et al. 1987) where spray coverage is difficult to accomplish. In addition, some populations of T. tabaci have developed resistance to insecticides in several parts of the world (Martin et al. 2003; Shelton et al. 2003, 2006; MacIntyre Allen et al. 2005b; Herron et al. 2008; Morishita 2008). Other studies have investigated the potential of other methods of control (biological control, host plant resistance, physical/mechanical control, and cultural practices) to reduce or contain populations of T. tabaci. Management strategies of $T$. tabaci will be discussed in the following sections.

Chemical Control. There is long history of use of insecticides to control T. tabaci. The first reports were the use of crude naphthalene (Maughan 1933, 1934) and crude naphthalene in combination with nicotine dust (Maughan 1934). A tartar emetic and brown sugar solution gave good control of T. tabaci on onion in the greenhouse but failed to control thrips in the field (Anderson and Walker 1940); however, Ewart et al. (1944) cited different studies in the field that successfully controlled T. tabaci and increased onion yields using tartar emetic. Before the introduction of DDT, the main insecticide to control T. tabaci was foliar sprays of tartar emetic (Ashdown and Watkins 1948), but economical control of T. tabaci was not completely successful until DDT was introduced (Richardson and Wene 1956). There are several reports in which DDT provided good control of T. tabaci (Chapman et al. 1945, Smith and Goodhue 1945, Hely 1946, Ashdown and Watkins 1948, Mayeux and Wene 1950, Wilcox and Howland 1948, Jacks and Harrison 1953), but resistance to chlorinated hydrocarbons emerged in the mid-1950s. In Texas, 18 insecticides were evaluated to control T. tabaci, and dieldrin, heptachlor, toxaphene, aldrin, and endrin did not provide control when used alone (Richardson and Wene 1956). After this, organophosphates and carbamates were commonly used (Casida and Quistad 1998). In 1986, studies showed that ethyl parathion applications provided poor control of T. tabaci (Cranshaw 1989). Pyrethroids have been widely used for the control of T. tabaci in onion. Permethrin was registered for onion and widely applied, but by 1994 it failed to control $T$. tabaci (Davis et al. 1995). Another pyrethroid, $\lambda$-cyhalothrin, was registered in 1996 and many growers used it exclusively during 1997 and 1998. Some populations of T. tabaci in onion growing areas have developed resistance to pyrethroid and organophosphate insecticides in New York (Shelton et al. 2003, 2006), New Zealand (Martin et al. 2003), Canada (MacIntyre Allen et al. 2005b), Australia (Herron et al. 2008), and Japan (Morishita 2008).

Recently, several new selective insecticides belonging to novel classes of chemistry such as abamectin, cyantraniliprole, spinosad, spinetoram, and spirotetramat have shown excellent control of $T$. tabaci infes- tations (Nault and Hessney 2008, 2010). In some cases, botanical insecticides have been effective against $T$. tabaci. Formulations of neem (Azadirachta indica A. Juss) have prevented the development of first larval instar to second instar in the laboratory (Klein et al. 1993, Ascher et al. 2000). However, formulations of plant derived products including neem, Chenopodium sp., and eucalyptus (Eucalyptus L'Hér) have either failed or provided only mediocre control of T. tabaci in the onion field (Nault and Hessney 2010; Nault et al. 2010)

It is difficult to control T. tabaci with insecticides because eggs are protected under leaf tissues, prepupae and pupae are in the soil or in the inner space between the leaves, and some adults in the inner leaf spaces may escape control. Reinfestations from surrounding vegetation and immigration of thrips from nearby harvested onion fields may also contribute to rapid increases in populations.

When an insecticide fails to control insect pests in the field, it is necessary to conduct insecticide resistance assays. Field performance of insecticides may be affected by environmental factors and poor coverage of the crop (Shelton et al. 2003). An appropriate technique for conducting insecticide resistance assays would be to bring the insect populations from the field and culture them under laboratory conditions until adequate numbers are accessible for testing, but this presents several problems with thrips. Thrips are difficult to keep in cages because of their small size and can contaminate or can be contaminated by other colonies and plant material on which thrips are reared may be contaminated. Also, resistance may change over time, so rearing thrips for generations and then conducting a bioassay on these later generations should be a concern (Rueda and Shelton 2003). With these concerns in mind, Rueda and Shelton (2003) developed a technique to evaluate T. tabaci susceptibility of some insecticides and named it the thrips insecticide bioassay system (TIBS). Using TIBS, thrips are collected from onion plants in fields and placed directly into a plastic $0.5-\mathrm{ml}$ microcentrifuge tube previously treated with an insecticide. Using this technique, studies have been able to identify $T$. tabaci resistance to different chemical insecticides within $24 \mathrm{~h}$ (Shelton et al. 2003, 2006; Rueda and Shelton 2003).

Insect species with a short life cycle and high fecundity can colonize crops rapidly and have a great potential to develop resistance to insecticides (Lewis 1997a). Polyphagous species are especially good at detoxifying a variety of plant toxins and this physiological adaptation can lead in the development of resistance to insecticides (Krieger et al. 1971). Insecticide resistance in thrips is a complex problem because it is necessary to understand genetic, biochemical, and toxicological properties of the mechanisms of resistance of the insect (Lewis 1997a). Recently, Toda and Morishita (2009) studied mutations of the sodium channel in T. tabaci populations resistant to pyrethroid insecticides and identified three major mutations 
(M918T, T929I, and L1014 F) responsible for this resistance.

Biological Control. There have been attempts to establish biological control agents for T. tabaci in different regions for $>60 \mathrm{yr}$, without significant success in the field (Parrella and Lewis 1997). In general, natural enemies affect only a small portion of the thrips population and their effect is unnoticed (Lewis 1973). T. tabaci usually seek protection in the inner leaves of onions and only when they come out of their refuge they are vulnerable to parasitoids and predators. Also, biological control in onion fields poses a monumental challenge because the crop is managed intensively with broad-spectrum insecticides and fungicides. However, the use of selective insecticides and action thresholds could create windows during the season in which biological control organisms could be helpful.

Waterhouse and Norris (1989) listed >90 natural enemies of T. tabaci worldwide, including predators and parasitoids insects (orders: Orthoptera, Hemiptera, Thysanoptera, Coleoptera, Neuroptera, Diptera, and Hymenoptera), predacious mites (families: Anystidae, Erythraeidae, and Phytoseiidae), and pathogenic fungi (classes: Zygomycetes and Hyphomycetes). The main predators of thrips include mites, heteropterans such as Orius sp., lacewing larvae, ladybird larvae, hoverfly larvae, small spiders, and other thrips (Kirk 1997). The main parasitoids of thrips are endoparasitoid wasps (Loomans et al. 1995) of the family Eulophidae, including species from the genera Ceranisus, Goetheana, Entedonastichus, and Thripobius (Kirk 1997). Adult wasps lay an egg inside the thrips larva. The wasp larva develops inside the thrips, killing it, and emerging from the larva, prepupa, or pupa (Kirk 1997).

Ceranisus menes (Walker) parasitizes T. tabaci and other thrips species (Sakimura 1937, cited by Kirk 1997). Some thrips species were able to escape parasitism by struggling, but larvae of T. tabaci do not. Samples taken from the field in Japan showed up to $88 \%$ parasitism of $T$. tabaci by C. menes and an average of $34 \%$. The parasitoid wasps showed a density-dependent effect that seemed to regulate T. tabaci populations, and the parasitism effectiveness increased through time (Sakimura 1937, cited by Kirk 1997).

Butt and Brownbridge (1997) listed fungal pathogens that were isolated or proven to be pathogenic to different thrips species. Fungi affecting T. tabaci includes Neozygites parvispora, N. cucumeriformis, Zoophthora radicans, and Entomophthora thripidum (class Zygomycetes); Verticillium lecanii, Beauveria bassiana, Aspergillus sp., Paecilomyces fumosoroseus, Metarhizium anisopliae, and Sporothrix sp. (class Hyphomycetes). However, it is unlikely that fungi alone can reduce population of thrips effectively, or be a substitute for chemical insecticides (Butt and Brownbridge 1997).

There have been attempts to assess the potential of entomopathogenic nematodes for control of T. tabaci. Elad et al. (2004) conducted four field trails using spray applications of nematodes (Steinernema feltiae and Heterorhabditis bacteriophora) alone or in combination with pathogenic fungi (Lecanicillium muscarium formerly Verticillium lecanii, Paecilomyces fumosoroseus, and Beauveria bassiana). In two trials, significant reductions in the number of thrips per plant were recorded for the treatments S. feltiae $+P$. fumosoroseus and S. feltiae + L. muscarium $1 \mathrm{wk}$ after the final application (three times in total). However, in the other two trials, there were no significant differences between the treatments and the control. In another study, Al-Siyabi et al. (2006) carried out experiments with the nematode Heterorhabditis indicus against $T$. tabaci at different concentrations by using foliar and soil treatments. A treatment of 1.5 million nematodes per $\mathrm{m}^{2}$ caused $70 \%$ mortality with soil applications and $55 \%$ with foliar applications. These studies demonstrate the success of entomopathogenic nematodes to control T. tabaci; however, more studies are needed to reveal the true impact for commercial production.

In summary, thrips control based on natural enemies does not seem to play a significant role in pest management programs in the field (Parrella and Lewis 1997). Whether this can change with the use of more selective insecticides should be a topic of research.

Cultural Control. Traps are used in greenhouses to reduce and monitor insect pests (Jacobson 1997) and in the field to monitor them. In a field experiment, Kirk (1984) used water traps and observed that white color attracted twice as many T. tabaci as yellow and blue traps, but in a similar experiment the same colors (white, yellow, and blue) were equally preferred (Czencz 1987). Pale blue was most attractive to $T$. tabaci compared with white, green, yellow, gray, and

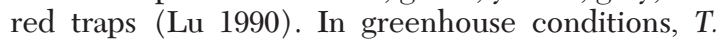
tabaci were more attracted to shades of blue and yellow than white (Brødsgaard 1993). MacIntyreAllen et al. (2005a) compared sticky traps with $T$. tabaci counts in onion fields and found that white sticky traps detected thrips earlier than plant counts. Recently, Davidson et al. (2009) studied the effect of pyridine compounds on $T$. tabaci populations attracted to white water traps in an onion field and observed that ethyl isonicotinate, methyl isonicotinate, and ethyl nicotinate caught 18, 12, and 4 times more thrips, respectively, than the control. In a similar experiment, Wogin et al. (2010) combined ethyl isonicotinate and ethyl nicotinate and caught 5-9 times more T. tabaci than traps with ethyl nicotinate only but caught similar numbers to traps with ethyl isonicotinate only.

Mechanical barriers and UV-reflectance have been examined for reducing thrips infestations (Parrella and Lewis 1997). Larentzaki et al. (2008a) studied the effect of kaolin particle film on T. tabaci in onion and found that it had significant negative effects on oviposition, feeding and development of T. tabaci under laboratory conditions and thrips populations were significantly lower on kaolin-treated plots in field conditions. Lu (1990) observed that silver mulches more effectively repelled T. tabaci when shallots, Allium cepa var. aggregatum G. Don (1827), were planted at 
12- by $12-\mathrm{cm}$ spacing than when planted at 3 by $3 \mathrm{~cm}$ and when used at the seedling stage than at plant maturity. Larentzaki et al. (2008b) evaluated the impact of straw mulch on T. tabaci in onion. In the field, they observed that straw mulch-treated plots had significantly less thrips and action thresholds were reached in straw mulch treatments 1-2 wk later than in control plots but yield was not significantly different between plots. In laboratory conditions, pupation was reduced by $54 \%$ in onion plants grown in straw mulch compared with a bare soil treatment.

Sanitation through destruction of cull onions, volunteer onion plants and weed hosts in the field after harvest is essential because they can serve as a T. tabaci overwintering site (Larentzaki et al. 2007). Volunteer onion plants, produced from cull onions, are sometimes found in high densities in onion fields when the onion crop is not present and they serve as a suitable host for thrips before the onions are planted in the spring and after onions are harvested in the fall. Because volunteer onions do not remain green during the winter, onion culls may serve as an overwintering site, as well as feeding and oviposition sites in the spring (Larentzaki et al. 2007). Removal of volunteer onion plants is also important because they are one of the few sources of primary inoculum of IYSV (Gent et al. 2006). T. tabaci also has been found colonizing different weeds species late in the fall (Larentzaki et al. 2007, Smith 2010).

Heavy rains can dislodge thrips and leave droplets on the leaves and drown T. tabaci, causing dramatic populations decreases (Harris et al. 1935, North and Shelton 1986a). Overhead irrigation of onion crops can cause similar reductions and this effect was comparable with the use of insecticides in areas in Australia (Passlow 1957). However, this may be difficult to implement in large-scale onion fields, and our experience reducing $T$. tabaci populations with overhead irrigation has given inconsistent results.

In field conditions, intercropping of vegetables with other plant species has been shown to reduce pest populations and may reduce or eliminate chemical control (Theunissen 1994). Intercropping has been successful in reducing T. tabaci infestations in tropical and temperate climates (Parrella and Lewis 1997). In Egypt, Afifi and Haydar (1990) reported that intercropping of onion and garlic (Allium sativum $\mathrm{L}$.) with tomato (Solanum lycopersicum L.) reduced infestations of T. tabaci by 80\%. In England, intercropping of onions with carrots (Daucus carota $\mathrm{L}$.) decreased $T$. tabaci populations by $50 \%$, and it was more effective when single rows of each crop were closely alternated, possibly because carrot foliage hid the onions from thrips view (Uvah and Coaker 1984).

Host Plant Resistance. Host plant resistance is an important foundation of integrated pest management (IPM) (Panda and Khush 1995, Kennedy 2008) and may offer a long-term solution to T. tabaci control and reduce the use of insecticides, which would lower environmental hazards and minimize the evolution of resistance to insecticides.
It had been reported that onion cultivars with white bulbs were more resistant to $T$. tabaci than cultivars with red bulbs (Verma 1966, Lall and Singh 1968); however, further work by Brar et al. (1993) did not find any such relationship. In New York state, MacLeod (1933) categorized 20 onion cultivars as susceptible or resistant by counting the number of $T$. tabaci present on the plants every $2 \mathrm{wk}$ during the period of infestation and suggested eight of the cultivars were resistant. However, caution should be observed with results from such "choice tests" in the field because resistance may not hold up when only one cultivar is grown.

Jones et al. (1934) observed that inner leaves of susceptible onion cultivars were flat and closer together, which provided more shelter for T. tabaci. On the contrary, the most resistant cultivar, 'White Persian', has inner leaves with a circular shape that were more separated from each other. When leaves were tied together artificially, T. tabaci populations increased on White Persian, suggesting the architecture of the plants was important. Jones et al. (1935) compared T. tabaci populations on 44 onion cultivars with White Persian. All cultivars tested had significantly higher numbers of T. tabaci than the resistant cultivar, which has thick, light green leaves and an open type of canopy. A similar type of leaf structure was observed in 'Nebuka', which had less T. tabaci compared with three other onion cultivars (Coudriet et al. 1979).

Pawar et al. (1987) screened 64 onion cultivars for resistance to T. tabaci and found that 17 that had the lowest number of T. tabaci larvae had leaves with a circular shape and wider angle between the central leaves. In a similar study, three of 28 onion cultivars classified as resistant had a wider angle between central leaves (Patil et al. 1988). Hudák and Pénzes (2004) associated low populations of $T$. tabaci with the shape of leaves and the angle of divergence of the two innermost leaves. In another study, six of 61 genotypes screened for resistance sustained fewer T. tabaci than the other cultivars (Brar et al. 1993). Loges et al. (2004a, 2004b) showed a relationship with the low number of larvae found on 'Duquesa' with the fewest leaves and largest angle between the central leaves, compared with seven other onion cultivars.

In a recent study, Diaz-Montano et al. (2010) screened 49 onion cultivars and found 11 resistant to T. tabaci. All the resistant cultivars had yellow-green colored foliage compared with the susceptible cultivars that all had blue-green color foliage. Although the authors did not examine the morphological or chemical basis for these color differences, they suggested that such differences in color are strongly associated with resistance.

\section{Conclusions}

T. tabaci is a well-established primary pest of onion worldwide that causes yield reductions by its direct feeding; and, more recently, by its transmission of IYSV and other pathogens. Management of T. tabaci over the past $60 \mathrm{yr}$ has relied primarily on the use of 
insecticides, but this in turn has led to many cases of insecticide resistance. Although insecticides will likely continue to be useful as components of an overall IPM program, there is an urgent need to incorporate other strategies, such as those mentioned in this review.

One seemingly underutilized strategy is the use of host plant resistance. Although published studies since the 1930s have suggested this as a viable strategy, it does not seem that commercial companies have emphasized this strategy in their research and development programs. Probably, this is because the factor(s) responsible for resistance have not been well defined and thus cannot be easily incorporated into a breeding program. Cultivars that we have recently identified as being resistant do include some commercial cultivars, and we have suggested such resistance is associated with leaf color (Diaz-Montano et al. 2010), but considerably more work needs to be done before such knowledge can be incorporated into a breeding program that would produce cultivars that are commercially acceptable for farmers and consumers.

The situation with developing resistance to IYSV is more complex because none of the cultivars we examined showed any tolerance to this emerging disease and we are not aware of any other germplasm showing resistance. If onion cultivars, or if cultural practices can be implemented, that reduce the likelihood that $T$. tabaci will land on and colonize onions, it would be expected that the incidence of IYSV would be reduced. However, a more likely successful strategy would be to incorporate genes for resistance to IYSV into commercially acceptable onions, but we are not aware of any resistant germplasm. In such cases, it may be that genetically engineering onions to be resistant to IYSV may be the only viable solution. This strategy has proven extremely effective in controlling Papaya ringspot virus in papaya (Carica papaya L.) and several viruses in summer squash (Cucurbita spp.) (Shelton et al. 2008).

\section{Acknowledgments}

The publication costs of this review paper were funded by the Griswold Endowment, Department of Entomology, Cornell University.

\section{References Cited}

Afifi, F.M.L., and M. F. Haydar. 1990. Effect of different intercropping systems on onion and garlic infestation with the "cotton and onion thrips," Thrips tabaci Lind. Bull. Fac. Agric. Univ. Cairo 41: 639-648.

Al-Siyabi, A. A., M. M. Kinawy, M. Al-Ansri, A. N. Mahar, S. R. Gowen, and N. G. Hague. 2006. The susceptibility of onion thrips, Thrips tabaci to Heterorhabditis indicus. Commun. Agric. Appl. Biol. Sci. 71: 239-243.

Ananthakrishnan, T. N. 1973. Thrips: biology and control. MacMillan, New Delhi, India.

Ananthakrishnan, T. N. 1990. Reproductive biology of thrips. Indira Publishing House, Oak Park, MI.

Anderson, L. D., and H. G. Walker. 1940. Notes on the control of onion thrips. J. Econ. Entomol. 33: 278-280.
Arrieche, N., R. Paz, A. Montagne, and J. Morales. 2006. Estudios biologicos de Thrips tabaci Lindeman (Thysanoptera: Thripidae) en cebolla, en el estado Lara, Venezuela. Bioagro 18: 149-156.

Ashdown, D., and T. C. Watkins. 1948. Field studies on control of onion thrips in New York. J. Econ. Entomol. 41: 378-382.

Ascher, K.R.S., J. Meisner, and M. Klein. 2000. Neem-based biopesticides against the Western flower thrips (WFT) and the onion thrips. In Abstracts of presentations on selected topics at The XIVth International plant protection congress (IPPC) 2. NEEM (Azadirachta indica), 25-30 July 1999, Jerusalem, Israel. Phytoparasitica 28: 87-90.

Bailey, S. F. 1934. A winter study of the onion thrips in California. Calif. State Dep. Agric. Mon. Bull. 23: 149-152.

Bailey, S. F. 1938. Thrips of economic importance in California. Univ. Calif. Coll. Agric. Agric. Exp. Stn. Cir. 346.

Bournier, A. 1983. Les thrips: biologie, importance agronomique. INRA, Paris, France.

Brar, K. S., A. S. Sidhu, and M. L. Chadha. 1993. Screening onion varieties for resistance to Thrips tabaci Lind. and Helicoverpa armigera (Hübner). J. Insect Sci. 6: 123-124.

Brødsgaard, H. F. 1993. Coloured sticky traps for thrips (Thysanoptera: Thripidae) monitoring on glasshouse cucumbers. Bull. OILB/SROP 16: 19-22.

Butt, T. M., and M. Brownbridge. 1997. Fungal pathogens of thrips, pp. 399-433. In T. Lewis (ed.), Thrips as crop pests. CAB International, New York.

Capinera, J. L. 2001. Handbook of vegetable pests. Academic, New York.

Casida, J. E., and G. B. Quistad. 1998. Golden age of insecticide research: past, present, or future? Annu. Rev. Entomol. 43: 1-16.

Chambers, W. S., and R. W. Sites. 1989. Overwintering thrips fauna in croplands of the Texas south plains. Southwest. Entomol. 14: 325-328.

Chapman, A. J., L. C. Fife, and R. L. McGarr. 1945. DDT for the control of onion thrips. J. Econ. Entomol. 38: 608-609.

Chittenden, F. H. 1913. Insects injurious to the onion crop, pp. 319-334. Yearbook of the U.S. Department of Agriculture 1912

Coudriet, D. L., A. N. Kishaba, J. D. McCreight, and G. W. Bohn. 1979. Varietal resistance in onions to thrips. J. Econ. Entomol. 72: 614-615.

Cranshaw, W. S. 1989. Control of organophosphate resistant onion thrips, 1986. Insecticide Acaricide Tests 14: 128.

Czencz, K. 1987. The role of coloured traps in collecting thrips fauna, pp. 426 - 435. In J Holman, J. Pelikán, A.F.G Dixon, and L. Weismann (eds.), Population structure, genetics and taxonomy of aphids and Thysanoptera. Proceedings of International Symposia, 9-14 September 1985 Smolenice, Czechoslovakia. SPB Academic Publishing, Amsterdam, The Netherlands.

Davis, M., Y. Anandwala, M. Bommarito, and E. Grafus. 1995. Onion thrips control, 1994. Arthropod Manage. Tests 20: 99.

Davidson, M. M., R. C. Butler, and D.A.J. Teulon. 2009. Pyridine compounds increase thrips (Thysanoptera: Thripidae) trap capture in an onion crop. J. Econ. Entomol. 102: 1468-1471.

Diaz-Montano, J., M. Fuchs, B. A. Nault, and A. M. Shelton. 2010. Evaluation of onion cultivars for resistance to onion thrips (Thysanoptera: Thripidae) and iris yellow spot virus. J. Econ. Entomol. 103: 925-937. 
du Toit, L. J., and G. Q. Pelter. 2005. Susceptibility of storage onion cultivars to iris yellow spot in the Columbia Basin of Washington, 2005. Biol. Cult. Tests 20: V006.

Edelson, J. V., B. Cartwright, and T. A. Royer. 1986. Distribution and impact of Thrips tabaci (Thysanoptera: Thripidae) on onion. J. Econ. Entomol. 79: 502-505.

Edelson, J. V., and J. J. Magaro. 1988. Development of onion thrips, Thrips tabaci Lindeman, as a function of temperature. Southwest. Entomol. 13: 171-176.

Edelson, J. V., B. Cartwright, and T. A. Royer. 1989. Economics of controlling onion thrips (Thysanoptera: Thripidae) on onions with insecticides in south Texas. J. Econ. Entomol. 82: 561-564.

Elad, Y., I. Pertot, and A. Enkegaard. 2004. Combined use of insect pathogenic fungi and nematodes against the onion thrips, Thrips tabaci, in the field. Bull. OILB/SROP 27: 141-143.

Elmore, J. C. 1949. Thrips injury to onions grown for seed. J. Econ. Entomol. 42: 756-760.

Ewart, W. H., T. C. Watkins, and D. Ashdown. 1944. Insecticidal uses of tartar emetic: against onion thrips in New York. J. Econ. Entomol. 37: 269-276.

[FAO] Food and Agriculture Organization of the United Nations. 2009. FAO statistical yearbook 2009. FAO Statistics Division. (http:// faostat.fao.org/).

Fournier, F., G. Boivin, and R. K. Stewart. 1995. Effect of Thrips tabaci (Thysanoptera: Thripidae) on yellow onion yields and economic thresholds for its management, J. Econ. Entomol. 88: 1401-1407.

Gangloff, J. L. 1999. Population dynamics and insecticide resistance of onion thrips, Thrips tabaci Lindeman (Thysanoptera: Thripidae) in onions. Ph.D. Dissertation, Cornell University, Ithaca.

Gawaad, A.A.A., and A. Y. El-Shazli. 1970. Studies on Thrips tabaci Lindman. VI. New stage in life cycle. Z. Ang. Entomol. 66: 395-398.

Gawaad, A.A.A., and A. Y. El-Shazli. 1971. Studies on Thrips tabaci Lindman. VII. Effect of food on the life cycle. Z Ang. Entomol 67: 27-30.

Gent, D. H., H. R. Schwartz, and R. Khosla. 2004. Distribution and incidence of Iris yellow spot virus in Colorado and its relation to onion plant population and yield. Plant Dis. 88: 446-452.

Gent, D. H., L. J. du Toit, S. F. Fichtner, S. K. Mohan, H. R. Pappu, and H. F. Schwartz. 2006. Iris yellow spot virus: an emerging threat to onion bulb and seed production. Plant Dis. 90: 1468-1480.

Ghabn, A.A.A.E. 1948. Contribution to the knowledge of the biology of Thrips tabaci Lind. in Egypt. Bull. Soc. Fouad. I Entomol. 32: 123-174.

Gillette, C. P. 1893. A few common insect pests. Colo. State Agric. Coll. Agric. Exp. Stn. Bull. 24.

Guzman, S. P., P. Salazar, A. Trochez, and J. De la Cruz. 1996. Ciclo de vida, hábitos y comportamiento de Thrips tabaci Lindeman en cebolla de bulbo (Allium cepa). Rev. Colomb. Entomol. 22: 93-98.

Hall, J. M., K. Mohan, E. A. Knott, and J. W. Moyer. 1993. Tospoviruses associated with scape blight of onion ( $\mathrm{Al}$ lium cepa) seed crops in Idaho. Plant Dis. 77: 952

Harding, J. A. 1961. Effect of migration, temperature, and precipitation on thrips infestations in south Texas. J. Econ. Entomol. 54: 77-79.

Harris, H. M., C. J. Drake, and H. D. Tate. 1935. Observation on the onion thrips (Thrips tabaci Lind.). Iowa State Coll. J. Sci. 10: 155-171.

Hely, P. C. 1946. Control of Thrips tabaci on onions. Experiments with DDT and tartar emetic. Agric. Gaz. N.S.W. 57: 467-471.
Herron, G. A., T. M. James, and J. H. Mo. 2008. Australian populations of onion thrips, Thrips tabaci Lindeman (Thysanoptera: Thripidae), are resistant to some insecticides used for their control. Aust. J. Entomol. 47: 361364.

Hoepting, C. A., H. F. Schwartz, and H. R. Pappu. 2007. First report of Iris yellow spot virus on onion in New York. Plant Dis. 91: 327.

Horsfall, J. L. 1921. Sources of infestation of Thrips tabaci in Iowa. J. Econ. Entomol. 14: 493-496.

Hsu, C. L., C. A. Hoepting, M. Fuchs, A. M. Shelton, and B. A Nault. 2010. Temporal dynamics of iris yellow spot virus and its vector, Thrips tabaci (Thysanoptera: Thripidae), in seeded and transplanted onion fields. Environ. Entomol. 39: 266-277.

Hudák, K., and B. Pénzes. 2004. Factors influencing the population of the onion thrips on onion. Acta Phytopathol. Entomol. Hung. 39: 193-197.

Jacks, H., and R. A. Harrison. 1953. Control of onion thrips. II. Final selection of insecticides. N.Z. J. Sci. Technol. A 35: 164-167.

Jackson, M. B., and D. J. Osborne. 1970. Ethylene, the natural regulator of leaf abscission. Nature 225: 1019-1022

Jacobson, R. J. 1997. Integrated pest management (IPM) in glasshouses, pp. 639-666. In T. Lewis (ed.), Thrips as crop pests. CAB International, New York.

Jones, H. A., S. F. Bailey, and S. L. Emsweller. 1934. Thrips resistance in the onion. Hilgardia 8: 215-232.

Jones, H. A., S. F. Bailey, and S. L. Emsweller. 1935. Field studies of Thrips tabaci Lind. with special reference to resistance in onions. J. Econ. Entomol. 28: 678-680.

Kendall, D. M., and J. L. Capinera. 1987. Susceptibility of onion growth stages to onion thrips (Thysanoptera: Thripidae) damage and mechanical defoliation. Environ. Entomol. 16: 859-863.

Kendall, D. M., and J. L. Capinera. 1990. Geographic and temporal variation in the sex ratio of onion thrips. Southwest. Entomol. 15: 80-88.

Kendall, D. M., and L. B. Bjostad. 1990. Phytohormone ecology: herbivory by Thrips tabaci induces greater ethylene production in intact onions than mechanical damage alone. J. Chem. Ecol. 16: 981-991.

Kennedy, G. G. 2008. Integration of insect-resistant genetically modified crops within IPM programs, pp. 1-26. In J. Romeis, A. M. Shelton, and G. G. Kennedy (eds.), Integration of insect-resistant genetically modified crops within IPM programs. Springer, Dordrecht, The Netherlands.

Kirk, W.D.J. 1984. Ecologically selective coloured traps Ecol. Entomol. 9: 35-41

Kirk, W.D.J. 1997. Distribution, abundance and population dynamics, pp. 217-257. In T. Lewis (ed.), Thrips as crop pests. CAB International, New York.

Klein, M., J. Meisner, E. Ben-Moshe, N. E. Nemny, I. Caspy, and K.R.S. Ascher. 1993. Formulations of neem (Azadirachta indica) seed extracts inhibit growth of nymphs of the onion thrips, Thrips tabaci. Hassadeh 74: 189-193.

Krieger, R. L., P. P. Feeny, and C. F. Wilkinson. 1971. Detoxication enzymes in the guts of caterpillars: an evolutionary answer to plant defenses? Science 579-581.

Kritzman, A., M. Lampel, B. Raccah, and A. Gera. 2001. Distribution and transmission of Iris yellow spot virus. Plant Dis. 85: $838-842$

Lall, B. S., and L. M. Singh. 1968. Biology and control of the onion thrips in India. J. Econ. Entomol. 61: 676-679.

Larentzaki, E., A. M. Shelton, F. R. Musser, B. A. Nault, and J. Plate. 2007. Overwintering locations and hosts for onion thrips (Thysanoptera: Thripidae) in the onion crop- 
ping ecosystem in New York. J. Econ. Entomol. 100: 1194-1200.

Larentzaki, E., A. M. Shelton, and J. Plate. 2008a. Effect of kaolin particle film on Thrips tabaci (Thysanoptera: Thripidae), oviposition, feeding and development on onions: a lab and field case study. Crop Prot. 27: 727-734.

Larentzaki, E., J. Plate, B. A. Nault, and A. M. Shelton. 2008b. Impact of straw mulch on populations of onion thrips (Thysanoptera: Thripidae) in onion. J. Econ. Entomol. 101: 1317-1324.

Levy, D., and N. Kedar. 1970. Effect of Ethrel on growth and bulb initiation in onion. HortScience 5: 80-82.

Lewis, T. 1973. Thrips: their biology, ecology and economic importance. Academic, London, United Kingdom.

Lewis, T. 1997a. Chemical control, pp. 567-593. In T. Lewis (ed.), Thrips as crop pests. CAB International, New York.

Lewis, T. 1997b. Pest thrips in perspective, pp. 1-13. In T. Lewis (ed.), Thrips as crop pests. CAB International, New York.

Lindeman, K. 1889. Die schädlichsten insekten des tabak in Bessarabien. Bull. Soc. Imp. Nat. Moscou 2: 10-77.

Loges, V., M. A. Lemos, L. V. Resende, D. Menezes, J. A. Candeia, and V. F. Santos. 2004a. Correlações entre caracteres agronômicos associados à resistência a tripes em cebola. Hortic. Bras. 22: 624-627.

Loges, V., M. A. Lemos, L. V. Resende, D. Menezes, J. A. Candeia, and V. F. Santos. 2004b. Resistência de cultivares e híbridos de cebola a tripes. Hortic. Bras. 22: 222225.

Loomans, A.J.M., J. C. van Lenteren, M. G. Tommasini, S. Maini, and J. Riudavets. 1995. Biological control of thrips pests: a review on thrips parasitoids. Wageningen Agric. Univ. Pap. 95: 89-201.

Lu, F. M. 1990. Color preference and using silver mulches to control the onion thrips, Thrips tabaci Lindeman. Chin. J. Entomol. 10: 337-342.

MacIntyre-Allen, J. K., C. D. Scott-Dupree, J. H. Tolman, and C. R. Harris. 2005a. Evaluation of sampling methodology for determining the population dynamics of onion thrips (Thysanoptera: Thripidae) in Ontario onion fields. J. Econ. Entomol. 98: 2272-2281.

MacIntyre Allen, J. K., C. D. Scott-Dupree, J. H. Tolman, and C. R. Harris. 2005b. Resistance of Thrips tabaci to pyrethroid and organophosphorus insecticides in Ontario, Canada. Pest Manag. Sci. 61: 809-815.

MacLeod, G. F. 1933. Some examples of varietal resistance of plants to insect attacks. J. Econ. Entomol. 26: 62-67.

Martin, N. A., P. J. Workman, and R. C. Butler. 2003. Insecticide resistance in onion thrips (Thrips tabaci) (Thysanoptera: Thripidae). N.Z. J. Crop Hortic. 31: 99-106.

Maughan, F. B. 1933. Naphthalene for the control of the onion thrips. J. Econ. Entomol. 26: 143-147.

Maughan, F. B. 1934. Further studies on the control of the onion thrips. J. Econ. Entomol. 27: 109-112.

Mayer, D. F., J. D. Lunden, and L. Rathbone. 1987. Evaluation of insecticides for Thrips tabaci (Thysanoptera: Thripidae) and effects of thrips on bulb onions. J. Econ. Entomol. 80: 930-932

Mayeux, H. S., and G. P. Wene. 1950. Control of onion thrips with low volume sprays. J. Econ. Entomol. 43: 908-912.

McKenzie, C. L., B. Cartwright, M. E. Miller, and J. V. Edelson. 1993. Injury to onions by Thrips tabaci (Thysanoptera: Thripidae) and its role in the development of purple blotch. Environ. Entomol. 22: 1266-1277.

Mo, J., S. Munro, A. Boulton, and M. Stevens. 2008. Withinplant distribution of onion thrips (Thysanoptera: Thripidae) in onions. J. Econ. Entomol. 101: 1331-1336.
Molenaar, N. D. 1984. Genetics, thrips (Thrips tabaci L.) resistance and epicuticular wax characteristics of nonglossy and glossy onions (Allium cepa L.) Ph.D. Dissertation, University of Wisconsin, Madison.

Morishita, M. 2008. Pyrethroid-resistant onion thrips, Thrips tabaci Lindeman (Thysanoptera: Thripidae), infesting persimmon fruit. Appl. Entomol. Zool. 43: 25-31.

Morison, G. D. 1957. A review of British glasshouse Thysanoptera. Trans. R. Entomol. Soc. Lond. 109: 467-520.

Moritz, G. 1997. Structure, growth and development, pp. 15-63. In T. Lewis (ed.), Thrips as crop pests. CAB International, New York.

Moritz, G., D. C. Morris, and L. A. Mound. 2001. ThripsIDPest thrips of the world. An interactive identification and information system. CD-ROM published for ACIAR by CSIRO Publishing, Melbourne, Australia.

Mound, L. A. 1967. The British species of the genus Thrips (Thysanoptera). Entomol. Gaz. 18: 13-22.

Mound, L. A. 1973. Thrips and whitefly, pp. 229-242. In A. J. Gibbs (ed.), Viruses and invertebrates. Elsevier, New York.

Mound, L. A. 1997. Biological diversity, pp. 197-215. In T. Lewis (ed.), Thrips as crop pests. CAB International, New York.

Mound, L. A., and A. K. Walker. 1982. Terebrantia (Insecta: Thysanoptera). Fauna of New Zealand No. 1. DSIR, Wellington, New Zealand.

Murai, T., and S. Toda. 2001. Variation of Thrips tabaci in colour and size, pp. 377-378. In R. Marullo and L. Mound (eds.), Thrips, plants, tospoviruses: the millennial review. Proceedings of the 7th International Symposium on Thysanoptera, 2-7 July 2001, Reggio Calabria, Italy. CSIRO, Melbourne, Australia.

Nakahara, S. 1991. Systematics of Thysanoptera, pear thrips and other economic species, pp. 41-59. In B. L. Parker, M. Skinner, and T. Lewis (eds.), Towards understanding Thysanoptera. U.S. Dep. Agric., General Tech. Rep. NE147. USDA Forest Service, Northeastern Forest Experiment Station, Radnor, PA.

Nakahara, S. 1994. The genus Thrips Linnaeus (Thysanoptera: Thripidae) of the new world. U.S. Dep. Agric. Tech. Bull. 1822.

Nault, B. A., and M. L. Hessney. 2008. Onion thrips control in onion, 2007. Arthropod Manage. Tests 33: E20.

Nault, B. A., and M. L. Hessney. 2010. Onion thrips control in onion, 2009. Arthropod Manage. Tests. 35: E13.

Nault, B. A., and A. M. Shelton. 2010. Impact of insecticide efficacy on developing action thresholds for pest management: a case study of onion thrips (Thysanoptera: Thripidae) on onion. J. Econ. Entomol. 103: 1315-1326.

Nault, B. A., A. M. Shelton, J. L. Gangloff-Kaufmann, M. E. Clark, J. L. Werren, J. C. Cabrera-La Rosa, and G. G. Kennedy. 2006. Reproductive modes in onion thrips (Thysanoptera: Thripidae) populations from New York onion fields. Environ. Entomol. 35: 1264-1271.

Nault, B. A., C. L. Hsu, E. A. Smith, M. L. Hessney, M. Fuchs, and A. M. Shelton. 2010. Managing onion thrips and status of Iris yellow spot virus in New York, pp. 113-117. In Proceedings of the 2010 Empire State Fruit and Vegetable Expo. 25-27 January 2010, Syracuse, NY. Cornell Cooperative Extension and New York State Vegetable Growers Association.

North, R. C., and A. M. Shelton. 1986a. Ecology of Thysanoptera within cabbage fields. Environ. Entomol. 15: 520 526.

North, R. C., and A. M. Shelton. 1986b. Overwintering of the onion thrips, Thrips tabaci (Thysanoptera: Thripidae), in New York. Environ. Entomol. 15: 695-699. 
Osborn, H., and C. W. Mally. 1895. The western onion thrips (Thrips alii Gilette). Iowa Agric. Coll. Exp. Stn. Bull. 27: 139-142.

Packard, A. S. 1872. Insects injurious to field crops: the onion thrips, pp. 5-8. In Second annual report on the injurious and beneficial insects of Massachusetts. Wright and Potter, Boston, MA.

Panda, N., and G. S. Khush. 1995. Host plant resistance to insects. CAB International, Wallingford, United Kingdom.

Parrella, M. P., and T. Lewis. 1997. Integrated pest management (IPM) in field crops, pp. 595-614. In T. Lewis (ed.), Thrips as crop pests. CAB International, New York.

Passlow, T. 1957. Control of Thrips tabaci Lind. in onion crops in the Lockyer Valley. Queensl. J. Agric. Anim. Sci. 14: 53-72.

Patil, A. P., R. N. Nawale, D. S. Ajri, and P. R. Moholkar. 1988. Field screening of onion cultivars for their reaction to thrips. Indian Cocoa Arecanut Spices J. 12: 10-11.

Pawar, D. B., U. N. Mote, P. N. Kale, and D. S. Ajri. 1987. Identification of resistant sources for thrips in onion. Curr. Res. Rep. 3: 115-117.

Pedigo, L. P., S. H. Hutchins, and L. G. Higley. 1986. Economic injury levels in theory and practice. Annu. Rev. Entomol. 31: 341-368.

Pergande, T. 1895. Observations on certain Thripidae. Insect Life 7: 390-395

Pozzer, L., T. Nagata, M. I. Lima, E. W. Kitajima, R. de O. Resende, and A. C. de Ávila. 1994. "Sapeca": an onion disease in the Sub-Médio São Francisco region, Brazil, is caused by a tospovirus with a serologically distinct nucleocapsid protein. Fitopatol. Bras. 19: 321

Pozzer, L., I. C. Bezerra, R. Kormelink, M. Prins, D. Peters, R. de O. Resende, and A. C. de Ávila. 1999. Characterization of a tospovirus isolate of iris yellow spot virus associated with a disease in onion fields in Brazil. Plant Dis. 83: 345-350.

Richardson, B. H., and G. P. Wene. 1956. Control of onion thrips and its tolerance to certain chlorinated hydrocarbons. J. Econ. Entomol. 49: 333-335.

Rueda, A., and A. M. Shelton. 2003. Development of a bioassay system for monitoring susceptibility in Thrips tabaci. Pest Manag. Sci. 59: 553-558.

Rueda, A., F. R. Badenes-Perez, and A. M. Shelton. 2007. Developing economic thresholds for onion thrips in Honduras. Crop Prot. 26: 1099-1107.

Sakimura, K. 1937. The life and seasonal histories of Thrips tabaci Lind. in the vicinity of Tokyo, Japan. Oyo Dobuts. Zasshi 9: 1-24.

Salas, J., G. Morales, O. Mendoza, C. Alvarez, and A. Parra. 1993. Biología y hábitos de Thrips tabaci Lindeman (Thysanoptera: Thripidae) en cebolla, Allium cepa L. Agron. Trop. 43: 173-183.

Shelton, A. M., J. P. Nyrop, R. C. North, C. Petzoldt, and R. Foster. 1987. Development and use of a dynamic sequential sampling program for onion thrips, Thrips tabaci, on onions. J. Econ. Entomol. 80: 1051-1056.

Shelton, A. M., B. A. Nault, J. Plate, and J. Z. Zhao. 2003. Regional and temporal variation in susceptibility to $\lambda$-Cyhalothrin in onion thrips, Thrips tabaci (Thysanoptera: Thripidae) in onion fields in New York. J. Econ. Entomol. 96: 1843-1848.

Shelton, A. M., J. Z. Zhao, B. A. Nault, J. Plate, F. R. Musser, and E. Larentzaki. 2006. Patterns of insecticide resistance in onion thrips (Thysanoptera: Thripidae) in onion fields in New York. J. Econ. Entomol. 99: 1798-1804.

Shelton, A. M., M. Fuchs, and F. Shotkowski. 2008. Transgenic vegetables and fruits for control of insect and in- sect-vectored pathogens, pp. 249-272. In J. Romeis, A. M. Shelton, and G.G. Kennedy (eds.), Integration of insectresistant genetically modified crops within IPM programs. Springer, Dordrecht, The Netherlands.

Shipley, A. E. 1887. Onion disease at Bermuda (Peronospora schleideniana De Bary). Bull. Misc. Inf. Kew. 10: 1-23.

Shirck, F. H. 1951. Hibernation of onion thrips in southern Idaho. J. Econ. Entomol. 44: 1020-1021.

Sites, R. W., and W. S. Chambers. 1990. Initiation of vernal activity of Frankliniella occidentalis and Thrips tabaci on the Texas south plains. Southwest. Entomol. 15: 339-343.

Sites, R. W., W. S. Chambers, and B. J. Nichols. 1992. Diel periodicity of thrips (Thysanoptera: Thripidae) dispersion and the occurrence of Frankliniella williamsi on onions. J. Econ. Entomol. 85: 100-105.

Slingerland, M. V. 1896. The "white blast" in onions. Rural New Yorker 55: 561.

Smith, E. 2010. Identifying weed species hosts for onion thrips (Thrips tabaci Lindeman) and their potential as sources of Iris yellow spot virus (Bunyaviridae: Tospovirus) in New York onion fields. M.S. Thesis, Cornell University, Ithaca.

Smith, F. F., and L. D. Goodhue. 1945. DDT aerosols to control onion thrips and other pests in greenhouses. J. Econ. Entomol. 38: 173-179.

Srinivasan, S., S. Lingappa, and Gurumurthy. 1981. Dispersion of onion thrips, Thrips tabaci Lindeman. Entomon 6: 275-277.

Stannard, L. J. 1968. The thrips, or Thysanoptera, of Illinois. Ill. Nat. Hist. Surv. Bull. 29: 215-552.

Thaxter, R. 1890. Notes in answer to inquiries concerning injurious insects. Conn. Agric. Exp. Stn. Rep. 1889.

Theunissen, J. 1994. Intercropping in field vegetable crops: pest management by agrosystem diversification-an overview. Pestic. Sci. 42: 65-68.

Theunissen, J., and H. Legutowska. 1991. Thrips tabaci Lindeman (Thysanoptera: Thripidae) in leek: within-plant distribution. J. Appl. Entomol. 112: 309-316.

Thind, T. S., and J. S. Jhooty. 1982. Association of thrips with purple blotch infection on onions plants caused by Alternaria porri. Indian Phytopathol. 35: 696-698.

Toda, S., and M. Morishita. 2009. Identification of three point mutations on the sodium channel gene in pyrethroid-resistant Thrips tabaci (Thysanoptera: Thripidae). J. Econ. Entomol. 102: 2296-3000.

Triplehorn, C. A., and N. F. Johnson. 2005. Borror and Delong's introduction to the study of the insects, 7th ed. Thomson Brooks/Cole, Belmont, CA

Uvah, I.I.I., and T. H. Coaker. 1984. Effect of mixed cropping on some insect pests of carrots and onions. Entomol. Exp. Appl. 36: 159-167.

Verma, S. K. 1966. Studies on the host preference of the onion thrips, Thrips tabaci Lindeman to the varieties of onion. Indian J. Entomol. 28: 396-398.

Vierbergen, G., H. Kucharczyk, and W.D.J. Kirk. 2010. A key to the second instar larvae of the Thripidae of the Western Palaearctic region (Thysanoptera). Tijdschr Entomol. 153: 99-160.

Waiganjo, M. M., J. M. Mueke, and L. M. Gitonga. 2008. Susceptible onion growth stages for selective and economic protection from onion thrips infestation, pp. 193200. In R. K Prange and S. D. Bishop (eds.), Proceedings, Symposium: sustainability through integrated and organic horticulture. International symposium of the International Society for Horticultural Science (ISHS), 13-19 August 2006, Seoul, Korea. Publication Acta Horticulturae. 767. International Society for Horticultural Science, Leuven, Belgium. 
Waterhouse, D. F., and Norris. 1989. Biological control: Pacific prospects-Supplemental 1. Australian Centre for International Agricultural Research-ACIAR Monogr. 12.

Webster, F. M. 1901. The onion thrips, Thrips tabaci Lindem. Columbus Horticultural Society. Q. J. Proc. 16: 74-80.

Weiss, M. J., and R. J. Beshear. 1987. Seasonal distribution of the flower thrips (Frankliniella tritici (Fitch)) and onion thrips (Thrips tabaci Lindeman) (Thysanoptera: Thripidae) on safflower in eastern Montana. Can. Entomol. 119: $399-401$.
Wilcox, J., and A. F. Howland. 1948. DDT Dust for control of onion thrips. J. Econ. Entomol. 41: 694-700.

Wogin, M. J., R. C. Butler, D.A.J. Teulon, and M. M. Davidson. 2010. Field response of onion thrips and New Zealand flower thrips to single and binary blends of thrips lures. Can. Entomol. 142: 75-79.

Received 16 July 2010; accepted 3 November 2010. 